\title{
The Effect of Intracerebroventricular Injection of Beta Amyloid Peptide (1-42) on Caspase-3 Activity, Lipid Peroxidation, Nitric Oxide and NOS Expression in Young Adult and Aged Rat Brain
}

\author{
Amiloid Beta Peptid (1-42)'nin Intraserebroventriküler Injeksiyonunun \\ Genç Erişkin ve Yaşlı Sıçanlarda Caspaz-3 Aktivitesi, Lipid \\ Peroksidasyon, Nitrik Oksit ve NOS Ekspresyonu Üzerindeki Etkileri
}

\author{
Ferihan CETIN ${ }^{1}$, Nuray YAZIHAN ${ }^{2}$, Sibel DINCER ${ }^{3}$, Gonca AKBULUT ${ }^{3}$ \\ ${ }^{1}$ Izmir University, Faculty of Medicine, Department of Physiology, Izmir, Turkey \\ ${ }^{2}$ Ankara University Faculty of Medicine, Department of Molecular Biology and Technology R\&D Unit, Ankara, Turkey \\ ${ }^{3}$ Gazi University, Faculty of Medicine, Department of Physiology, Ankara, Turkey
}

Presented in: Apoptosis World Congress, Luxembourg, 2008

Correspondence address: Ferihan CETIN / E-mail: ferihan@yahoo.com

\begin{abstract}
AIM: Intracerebroventricular (icv) administration of beta amyloid peptide (AB) in rats can be used to model certain aspects of Alzheimer disease (AD).The purpose of this study was to examine the effects of intracerebroventricular $A \beta(1-42)$ peptide injection on caspase-3 activity and expression of nNOS and iNOS, malondialdehyde (MDA), glutathione (GSH) and NOx in the hippocampus, temporal cortex and parietal cortex.

MATERIAL and METHODS: Groups were defined as 1) young adult control, 2) A $\beta$ (1-42) injected young adult, 3) aged control and 4) $A \beta$ (1-42) injected aged group. Stereotaxic surgery was performed. $A \beta$ (1-42) peptide $(5 \mu \mathrm{g} / 1 \mu \mathrm{l}$, in each icv) was administered bilateral intracerebroventricularly as a single injection.

RESULTS: Caspase-3 activity significantly increased in $A \beta$ (1-42) injected aged rats when compared with young adult rats. $A \beta$ (1-42) significantly increased lipid peroxidation in both young adult and aged rats. There was an increase in nNOS expression in the temporal cortex of $A \beta$ (1-42) injected aged rats.

CONCLUSION: The most significant increase was seen in hippocampus in caspase-3 levels of the Aged- A 1 1-42 group. nNOS expression in the hippocampus of aged rats was increased compared to young adult rats. However, nNOX expression in the hippocampus of A $\beta$ (1-42) injected aged rats decreased significantly.
\end{abstract}

KEYWORDS: Beta amyloid, Caspase 3 activity, Lipid peroxidation, Nitric oxide, Nitric oxide synthase, Hippocampus, Aging

öz

AMAÇ: Literatür bulguları, oksidatif stres ve kaspaz aktivitesinin amiolid beta peptid $(A \beta)$ 'in meydana getirdiği Alzheimer Hastalı̆̆ı(AH) nörotoksisitesinde ve yaşlanmada rolü olduğunu göstermektedir. İntraserebroventrikuler (icv) A $\beta$ peptid uygulamaları sıçanlarda AH'nı taklit etmek için kullanılmaktadır. Bu çalışmanın amacı, icv A $\beta$ (1-42) peptid uygulamasının 3-4 aylık genç erişkin ve 22-24 aylık yaşlı sıçanların hipokampus, temporal korteks ve parietal kortekslerinde kaspaz 3 aktivitesi, nNOS ve iNOS ekspresyonu, MDA,GSH ve NO düzeylerine olan etkilerini araştırmaktır.

YÖNTEM ve GEREÇLER: Gruplar: 1) Genç erişkin kontrol, 2) icv A $\beta$ (1-42) enjekte edilen genç erişkin, 3) Yaşılı kontrol 4) icv A $(1-42)$ enjekte edilen yaşlı grup. Stereotaksik cerrahi uygulanarak her bir serebral ventrikül içerisine $5 \mu \mathrm{g} / 1 \mu \mathrm{l} A \beta(1-42)$ peptid tek bir kez enjekte edildi. $A \beta$ (142) uygulamasından 72 saat sonra sıçanlar dekapite edilerek beyinleri hızla buz üzerinde çıkarıldı.

BULGULAR: $A \beta(1-42)$ enjekte edilen yaşlı sıçanlarda genç erişkinlere göre kaspaz 3 aktivitesi anlamlı olarak yüksek bulundu. $A \beta(1-42)$ enjekte edilen hem genç erişkin hem de yaşlı sıçanların temporal ve parietal kortekslerinde MDA düzeyleri anlamlı düzeyde artış gösterdi. nNOS ekspresyonu yaşlı kontrol grubunda genç erişkin kontrol gruba göre hipokampuste yüksek olarak bulundu.

SONUÇ: Yine hipokampuste $A \beta(1-42)$ uygulamasından sonra yaşlı grupta yaşlı kontrol grubuna göre nNOS ekspresyonunda azalma bulundu. Temporal kortekste ise nNOS ekspresyonu $A \beta(1-42)$ uygulamasından sonra yaşlı grupta artmış bulundu. iNOS ekspresyonu ise hiçbir grupta saptanmadı.

ANAHTAR SÖZCÜKLER: Beta amiloid, Kaspaz 3 aktivitesi, Lipid peroksidasyon, Nitrik oksit, Nitrik oksit sentaz, Hipokampus, Yaşlılık 


\section{INTRODUCTION}

Oxidative damage, mitochondrial dysfunction and inflammation underlie many common aging-related neurodegenerative diseases, including $A D(7,18)$. The major pathological hallmark of $A D$ is the accumulation of $A \beta$ peptides in the brain (24).

Nitric oxide (NO) is a signaling molecule produced by neurons and endothelial cells in the brain. NO is synthesized from L-arginine and oxygen by nitric oxide synthase: neuronal (nNOS), endothelial (eNOS), and inducible (iNOS) (14). A high level of $\mathrm{NO}$ is implicated in pathological process of neurological and aging-related disorders. $A$ single $A \beta$ administration into the rat hippocampus could induce increase of NOS activity and NO level. NO could damage DNA and irreversibly modify proteins such as tyrosine nitrosylation or thiol oxidation, which are common pathogenic mechanisms in several neurodegenerative diseases. On the other hand, NO-derived peroxynitrite could cause irreversible injury to the mitochondria, inhibiting all complexes. This leads to reduced ATP formation and induction of opening of the permeability transition pore, release of cytochrome $c$ and activation of caspase. It has been shown that $A \beta$ peptide triggers the activation of caspase- 3 , which eventually results in neuronal apoptosis (26).

Oxidative insults that induce neuronal apoptosis, including agents that induce membrane lipid peroxidation, have been shown to activate caspases (5). Increased lipid peroxidation was consistently observed in an animal model of Alzheimer amyloidosis. GSH is an important intracellular antioxidant and essential cofactor for antioxidant enzymes that protect against endogenous oxygen radicals (26). Despite this role, the induction of GSH synthesis seems not to be enough to protect the cells from the NO effect; the increase in GSH level occurs when caspase 3 is already activated and thus the apoptotic process is already in progress (11).

Currently, the aging process is believed to be closely related to increased oxidative stress. Reactive intermediates of oxidative stress affect the cellular redox status and induce apoptosis (2). Oxidative stress due to the loss of balance between ROS production and antioxidant defenses affects all the vital organs, resulting in aging $(2,18)$. Lipid peroxidation products and advanced glycation end-products may induce programmed changes in gene expression profile during aging. The increased production of radicals can induce oxidative stress, which leads to cell death (17). It was found that caspase-3, caspase- 6 , caspase- 7 , caspase- 9 and caspase- 2 undergo an age-associated increase in activity (25).

Evidence for the involvement of nNOS in AD is also provided by Thorns et al., who reported increased nNOS expression in those neurons with neurofibrillary tangles in the entorhinal cortex and hippocampus of AD patients (22).

In the light of the current literature, we investigated nNOS and iNOS expression, caspase-3 activity, NOx, MDA and GSH levels after icv injection of $A \beta$ 1-42 in hippocampus, temporal and parietal cortices in young adult and aged rats. This is the first study, to our knowledge, to compare the effects of $A \beta$ 1-42 administration in young adult and aged rat brains with these parameters.

\section{MATERIAL and METHODS}

\section{Animals}

The rats used in the present study were males of the Wistar albino strain. The young adult group was 3-4 months old and the aged group was 22-24 months old. The rats were housed in cages (four/cage) until surgery with ad libitum food and water and maintained on a 12-h light:dark cycle with lights on from $08: 00$ to $20: 00 \mathrm{~h}$, at $20-22^{\circ} \mathrm{C}$ room temperature. All animal manipulations were carried out according to the Ethical Comittee for the use and care of laboratory animals of Gazi University, Faculty of Medicine.

\section{i.c.v injection of $A \beta$ (1-42)}

The 24 rats were randomly assigned to four groups $(n=6 /$ group). Groups were 1. control young adult, 2. beta amyloid (1-42) injected young adult, 3. aged control, 4. beta amyloid (1-42) injected aged group. The $A \beta$ (1-42) peptide (American Peptide Company) dissolved in distilled water at the concentration of $5 \mu \mathrm{g} / \mu \mathrm{l}$ and the solution was incubated at $37^{\circ} \mathrm{C}$ for 1 week before use. The fibrillary form of beta amyloid was observed under the light microscope and then stereotaxic surgery was performed (Stoelting) under xylazine $(10 \mathrm{mg} /$ $\mathrm{kg}$, i.p.) and ketamine (80 mg/kg, i.p.) anesthesia. Holes were drilled in the skull over the lateral ventricle using the following coordinates: $0.8 \mathrm{~mm}$ posterior to bregma; $1.5 \mathrm{~mm}$ lateral to the sagittal suture (16). The needle of the Hamilton microsyringe (26-gauge) (Hamilton Company) was put $4 \mathrm{~mm}$ beneath the surface of the skull. $5 \mu \mathrm{g} / 1 \mu \mathrm{l}$ of the solution was injected into the right lateral ventricle and then $5 \mu \mathrm{g} / 1 \mu \mathrm{l}$ of the solution was injected into the left cerebral ventricle. Control rats were injected with distilled water using the same procedure. The animals were taken to the individual cages after the surgery. 72 hours after the surgery rats were sacrificed by decapitation and brains were rapidly removed on ice. Hippocampus, temporal and parietal cortex are dissected and were frozen in liquid nitrogen and then stored at $-80^{\circ} \mathrm{C}$ until use.

\section{MDA and GSH Determination}

GSH levels and lipid peroxidation was estimated by the thiobarbituric acid (TBARS) test for malondialdehyde as described previously (1).

\section{Caspase-3 Measurements}

Protein content of homogenates was determined with Bradford method. Then $100 \mu \mathrm{g}$ of protein containing samples were diluted with assay buffer and incubated at $25^{\circ} \mathrm{C}$ with the colorimetric substrates (Sigma): Ac-DEVD-pNA, Ac-YVAD$p N A$, IETD $p N A$, or LEHD-pNA. Results were calibrated with known concentrations of $p$-NA and expressed in pm substrate cleaved/minute and per microgram protein at $25^{\circ} \mathrm{C}$. 


\section{Western blotting}

For detection of nNOS protein, the tissue was homogenized in $50 \mathrm{mM}$ Tris- $\mathrm{HCl}$ buffer at $\mathrm{pH} 7.4$ containing $1 \mathrm{mM}$ EDTA, trypsin inhibitor phenylmethylsulfonyl fluoride, aprotinin and leupeptin and centrifuged at $30,000 \mathrm{xg}$ for $30 \mathrm{~min}$ at $4^{\circ} \mathrm{C}(15)$. Samples containing $10 \mu \mathrm{g}$ of protein for nNOS and $60 \mu \mathrm{g}$ of protein for iNOS were loaded in each lane of a $7 \%$ acrylamide gel in SDS for electrophoretic separation. The samples were then transferred to a PVDF membrane and were incubated with nNOS or iNOS primary antibodies (Calbiochem). The membranes were probed with HRP-conjugated anti-rabbit secondary antibody (Santa Cruz Biotechnology) and visualised by the ECL detection kit. The resultant blots were quantified by using the CCD image analyser system. Densitometric analyses were performed using the densitometric software Aida 2.1. The iNOS antibody reacted strongly with lysate obtained from LPS treated RAW264.7 cells, giving a band at $135 \mathrm{kDa}$. There was no iNOS expression in any group either in A $\beta$ 1-42 injected groups.

\section{NOx Assay}

Nitrite plus nitrate (NOx) which are the last and stabile products of NO were determined in tissue samples spectrophotometrically (21).

To evaluate the significance of differences between groups, statistical analysis of data was performed with one-way ANOVA with post hoc Bonferoni test.

\section{RESULTS}

MDA results are shown in Figure 1. A $\beta$ 1-42 increased MDA levels in the temporal cortex and parietal cortex of young adult and aged rats. GSH results are shown in Figure 2. Hip- pocampal GSH increased significantly in $A \beta$ 1-42 injected aged rats. Caspase 3 activity is shown in Figure 3. We found high caspase- 3 activity in hippocampus and temporal cortex in aged rats compared to young adults. $A \beta$ 1-42 significantly increased caspase- 3 activity in hippocampus, temporal cortex and parietal cortex both of young adult and aged rats. nNOS expression in hippocampus is shown in Figure 4A and arbitrary units in Figure 5. nNOX expression in the hippocampus of aged rats was increased significantly compared to young adult rats. However, nNOX expression in the hippocampus of $A \beta$ 1-42 injected aged rats decreased significantly. nNOS expression in the temporal cortex is shown in Figure $4 B$ and arbitrary units in Figure 5. A 1 1-42 increased nNOS expression in temporal cortex of aged rats. nNOS expression in the parietal cortex is shown in Figure 4C. There was no difference between the groups in nNOS expression in the parietal cortex. Absence of iNOS expression is shown in Figure 4D. There was no iNOS expression in hippocampus in any group either in $A \beta$ 1-42 injected groups. NOx levels are shown in Figure 6. $A \beta$ 1-42 significantly increased NOx levels in aged rats.

\section{DISCUSSION}

The current literature contains conflicting data concerning the dual role (neuroprotector/neurotoxic) that NO may play in the aging CNS (19). It is mostly believed that NO has neurotoxic effects on neurons, but we found no elevated NOx levels in aged rat brain compared to those of young adults. In the current study, we found significant high levels of NOx in the temporal cortex of $A \beta$ 1-42 injected aged rats compared to aged rats. It seems likely that, after intracerebroventricular injection of $A \beta 1-42$, it distributes through the parenchymal tissue and by the way both MDA and NOx levels increased in the temporal cortex of $A \beta$ 1-42 injected aged rats. There

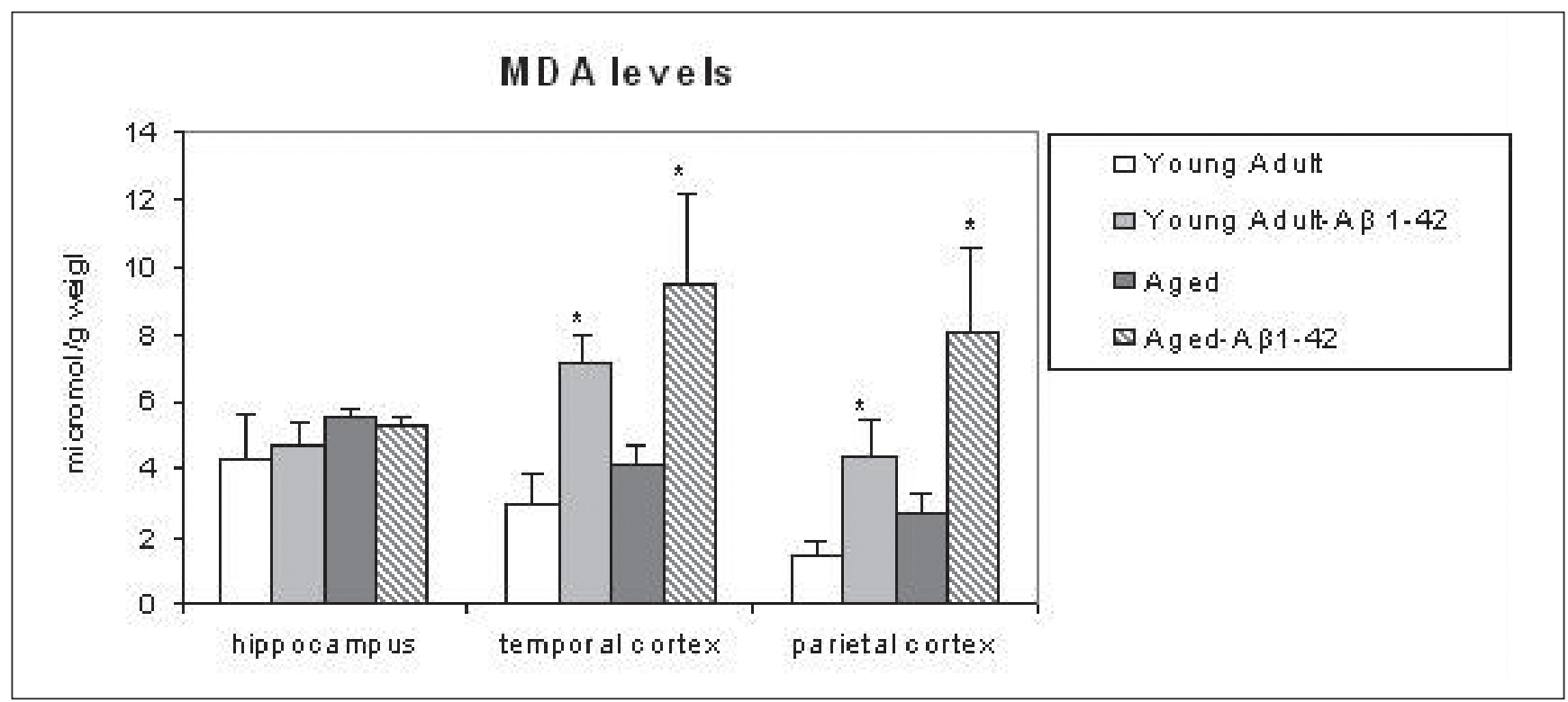

Figure 1: MDA levels of hippocampus, temporal and parietal cortex regions of the young adult, $A \beta$ 1-42 injected young adult, aged and $A \beta$ 1-42 injected aged rats brains. *Denotes significant difference $(p<0.05)$ both between young adult (Young Adult) and $A \beta$-injected young adult rats (Young Adult-Amyloid $\beta$ ), and aged and $A \beta$ 1-42 injected aged rats (Aged-Amyloid $\beta$ ). 


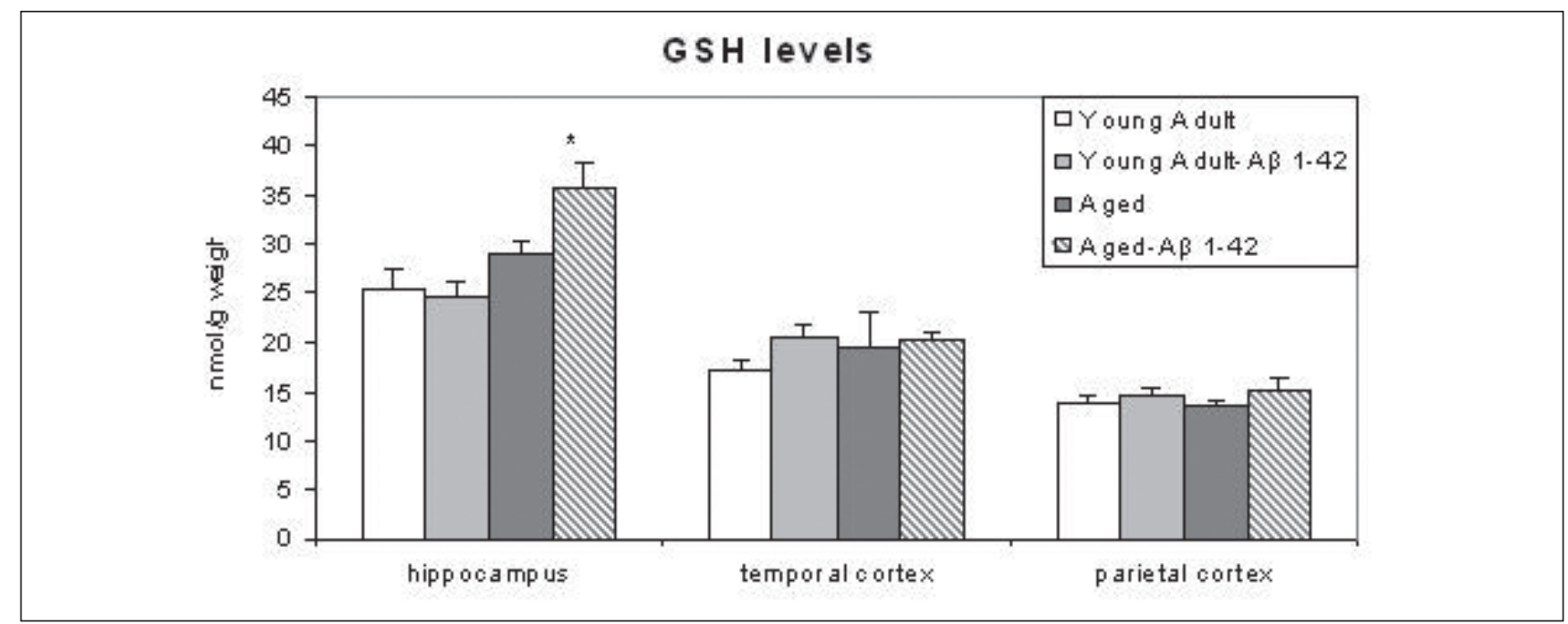

Figure 2: GSH levels of hippocampus, temporal and parietal cortex. *Denotes significant difference $(p<0.05)$ both between young adult (Young Adult) and $A \beta$-injected young adult rats (Young Adult-Amyloid $\beta$ ), and aged and A $\beta$ 1-42 injected aged rats (AgedAmyloid $\beta$ ).

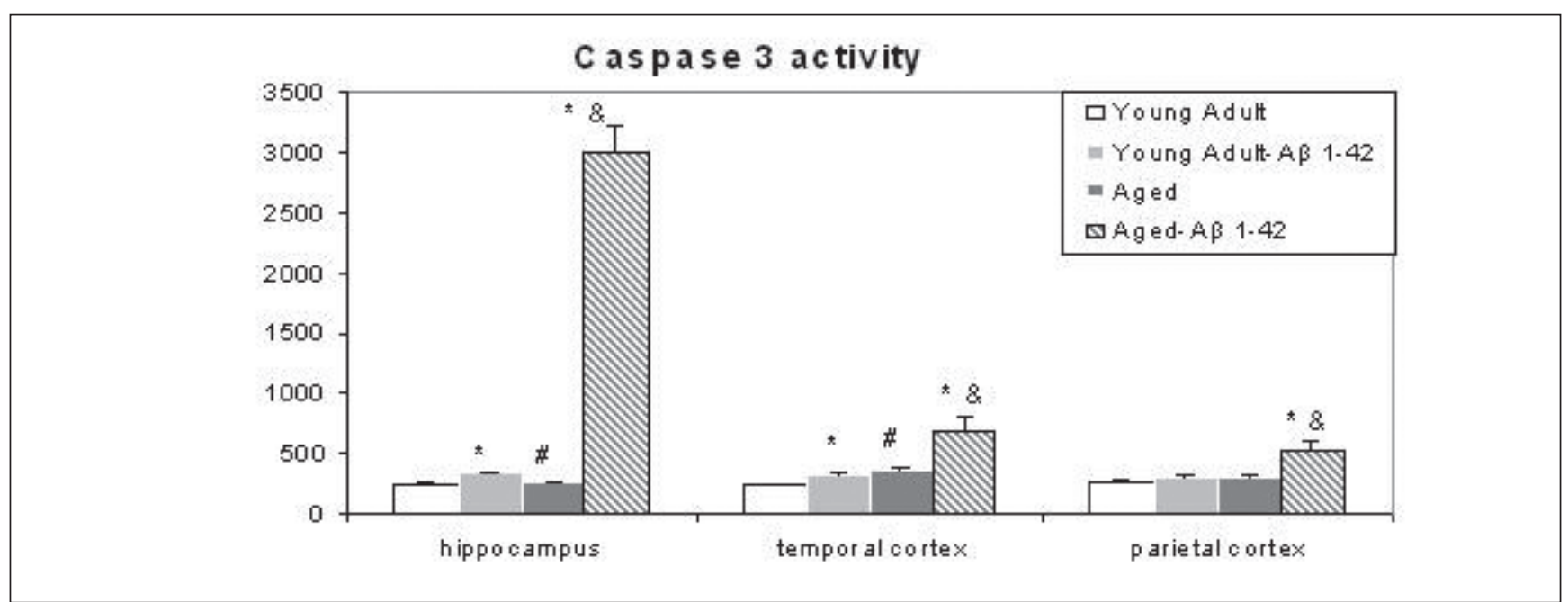

Figure 3: Caspase-3 levels in the hippocampus, temporal and parietal cortex. *Denotes significant difference $(p<0.01)$ both between young adult (Young Adult) and $A \beta$-injected young adult rats (Young Adult-Amyloid $\beta$ ), and aged and $A \beta$ 1-42 injected aged rats (AgedAmyloid $\beta$ ). "Denotes significant difference $(p<0.05)$ between Young Adult and Aged group. ${ }^{*}$ Denotes significant difference $(p<0.05)$ between Young Adult-Amyloid $\beta$ and Aged-Amyloid $\beta$.

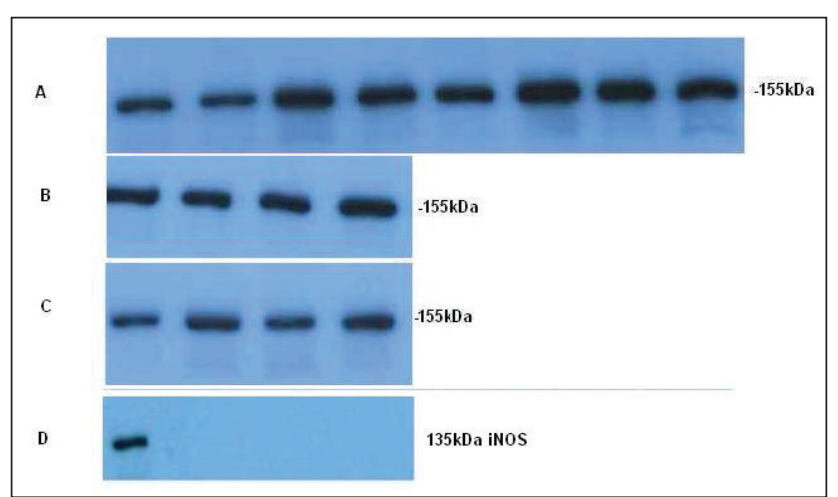

Figure 4: A) $155 \mathrm{kDa}$ band of nNOS on a typical Western blot in hippocampus supernatants of groups. Equal amounts of protein from two animals of the same group have been shown in order to Young Adult, Young Adult-Amyloid $\beta$, Aged and Aged-Amyloid $\beta$. (Lane 1-2 is Young Adult, lane 3-4 is Young Adult-Amyloid $\beta$, lane 5-6 is Aged and lane 7-8 is Aged-Amyloid $\beta$ group). B) $155 \mathrm{kDa}$ band of nNOS from temporal cortex. Lane 1 is Young Adult, lane 2 is Young Adult-Amyloid $\beta$, lane 3 is Aged, lane 4 is Aged-Amyloid $\beta$ group. C) $155 \mathrm{kDa}$ band of nNOS fom parietal cortex. Lane 1 is Young Adult, lane 2 is Young Adult-Amyloid $\beta$, lane 3 is Aged, lane 4 is Aged-Amyloid $\beta$ group. There is no difference in nNOS expression between the groups. D) Western blotting bands from rat hippocampus treated with anti iNOS antibody. First lane shows $135 \mathrm{kDa}$ band (iNOS) from positive control. Other lanes orders are as Young Adult, Young Adult-Amyloid $\beta$, Aged and Aged-Amyloid $\beta$. iNOS expression was not observed in any brain region. 


\section{nNOS Densitometry}

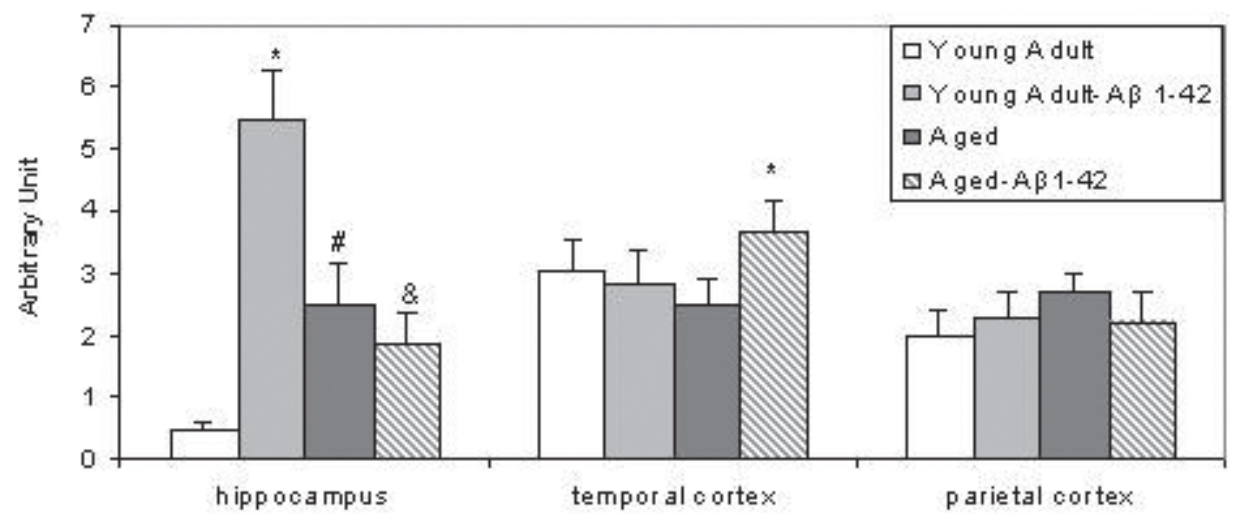

Figure 5: Arbitrary densitometric units of Western blotting of nNOS in hippocampus, temporal cortex and parietal cortex. *Denotes significant difference $(p<0.05)$ both between young adult (Young Adult) and A $\beta$-injected young adult rats (Young Adult-Amyloid $\beta$ ), and aged and $A \beta$ 1-42 injected aged rats (Aged-Amyloid $\beta$ ). "Denotes significant difference $(p<0.05)$ between Young Adult and Aged group. ${ }^{\circledR}$ Denotes significant difference $(p<0.05)$ between Young Adult-Amyloid $\beta$ and Aged-Amyloid $\beta$. ${ }^{+}$Denotes significant difference $(p<0.05)$ between Aged and Aged-Amyloid $\beta$ in temporal cortex.

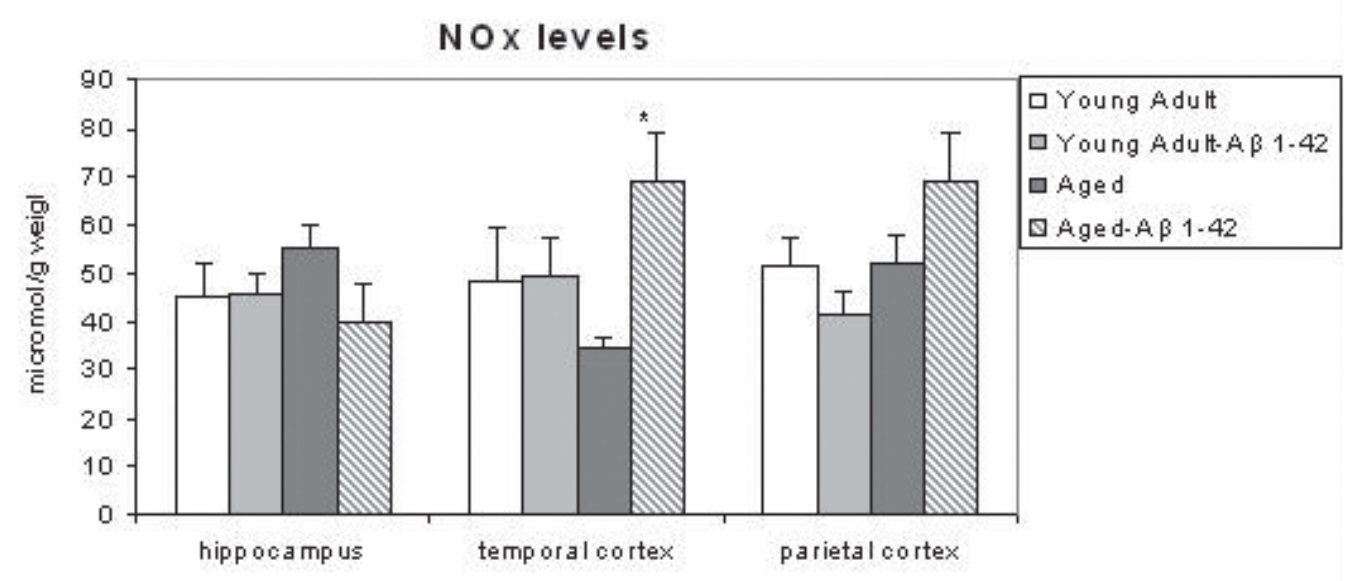

Figure 6: NOx levels ( $\mu \mathrm{mol} / \mathrm{g}$ tissue) in hippocampus, temporal cortex and parietal cortex of groups. *Denotes significant difference $(p<0.05)$ both between young adult (Young Adult) and $A \beta$-injected young adult rats (Young Adult-Amyloid $\beta$ ), and aged and $A \beta$ 1-42 injected aged rats (Aged-Amyloid $\beta$ ).

were no differences in MDA, GSH and NOx levels between the control groups of young adult and aged rats. In the current study, we also compared young adult and aged rat brain with regard to these parameters and did not observe increased MDA, GSH or NOx in aged rats.

It is now known that nNOS-expressing hippocampal neurons are more vulnerable to oxidative stress in aging and the Alzheimer brain (22) and A $\beta$ 1-42 is an important oxidative stress factor in the brain of aged rats. Maybe for this reason, and because hippocampal neurons which express nNOS are prone to oxidative insults, the present study found decreased nNOS expression in the hippocampus in $A \beta$ 1-42 injected aged rats. In this study, $A \beta$ 1-42 had a counter effect on nNOS expression in young adults and aged rats. $A \beta$ 1-42 injected aged rats showed decreased nNOS expression in the hippocampus, while $A \beta$ 1-42 injected young adult rats showed significant increase in nNOS expression but NOx levels were unchanged. In mild oxidative stress, intracellular GSH levels increase (8) and try to compensate for oxidative stress in young adult rats (6), the results of this study suggest that the aged rat brain does not successfully offset the oxidative stress. $A \beta$ 1-42 increased lipid peroxidation in temporal cortex of both young adult and aged rat, which may be because of the close proximity of intracerebroventricular $A \beta$ 1-42 injection, adjacent to the temporal cortex.

Previous studies have shown that NOS expression is altered in $A D$ and it has been suggested that iNOS plays a role in the formation of plaques and neurofibrillary tangles (22). 
In this study, we did not observe expression of iNOS in any brain region after injection of $A \beta 1-42$; this may be because a single injection is insufficient to induce chronic inflammatory responses. Cells can usually tolerate mild oxidative stress, which often results in up-regulation of the synthesis of antioxidant defense systems in an attempt to restore the oxidant/antioxidant balance (8).

Although this study found that nNOS expression was increased in aged rat hippocampus, no positive correlation was found with NOx. This may be because free radical superoxide reacts with NO, producing the powerful oxidant peroxynitrite $(8,19)$.

$A \beta$ (25-35) activated nNOS in the cerebral cortex and hippocampus without effect on iNOS activity (20). Since $\mathrm{A} \beta$ neurotoxicity is believed to be mediated by $\mathrm{NO}$ and the potential toxic effects of NO depend on the intracellular source of the molecule (i.e. isoform-specific) and extracellular conditions (11). A progressive loss of nNOS immunoreactive neurons in the layer II of the entorhinal cortex and, to a lesser extent, in the CA1 and CA3 hippocampal sub-fields in patients with $A D$, clearly demonstrates that nNOS-expressing neurons are affected in AD (22).

Glutathione peroxidase activity is significantly increased in $A D$ hippocampus, glutathione reductase activity is increased in hippocampus and amygdala, and catalase activity is elevated in the hippocampus and temporal cortex in AD (12). GSH is located in both the cytosol and the mitochondria within cells and acts as a vital endogenous antioxidant to combat oxidative stress (3). Glutathione is known to protect cells against apoptosis, protected hippocampal neurons, which is consistent with the suggestion of involvement of $\mathrm{ONOO}^{-2}$ mediated cellular events in neuronal apoptosis $(4,18)$.

It appears that structural changes in neurons may be the primary neurobiological alterations that impair function in normal aging and differ from those in neurodegenerative disorders such as AD (17).

This is the first study to examine caspase- 3 activation and nNOS expression in hippocampus, temporal and parietal cortices in aged rats after single icv injection of $A \beta$ 1-42. This model, icv injection of $A \beta$ 1-42 to aged rats, seems to be a simple and convenient animal model for AD.

In this study, it would be better to complete with the determination of NOS activity (for example it could be determined by NADPH diaphorase histochemistry) and with the eNOS expression. And it would be better if we could count the number of neurons in the mentioned brain areas to clarify and compare possible neuronal loss between the groups. It would be better to undertake determinations of the s-nitrosoglutathione (GSNO), as it could complete the study of the NO/NOS system, and it would enable us to better understand and justify the results of glutathione.

In conclusion, the damaging effects of low physiological concentrations of $A \beta$ might initially be overcome by an adaptive response in young adults. However, when age- related secondary stress occurs, mitochondrial impairment might lead to the induction of cell death and may be due to this nNOS expression decreased in icv injected $A \beta$ 1-42 aged rats especially in the hippocampus.

\section{REFERENCES}

1. Aykac G, Uysal M, Yalcin AS, Kocak-Toker N, Sivas A, Oz H: The effect of chronic ethanol ingestion on hepatic lipid peroxide, glutathione, glutathione peroxidase and glutathione transferase in rats. Toxicology 36: 71-76, 1985

2. Beckman $\mathrm{KB}$, Ames $\mathrm{BN}$ : The free radical theory of aging matures. Physiol Rev 78:547-581, 1998

3. Boyd-Kimball D, Sultana R, Abdul HM, Butterfield DA: Gamaglutamylcysteine ethyl ester-induced up-regulation of glutathione protects neurons against Abeta(1-42)-mediated oxidative stress and neurotoxicity: Implications for Alzheimer's disease. J Neurosci Res 79(5)700-706, 2005

4. Butterfield DA, Lauderback CM: Lipid peroxidation and protein oxidation in Alzheimer's Disease brain: Potential causes and consequences involving Amyloid $\beta$-Peptideassociated free radical oxidative stress. Free Rad Biol Med 32(11):1050-1060, 2002

5. Camandola S, Poli G, Mattson MP: Lipid Peroxidation Product 4-hydroxynonenal increases AP-1 binding activity through caspase activation in neurons. J Neurochem 74(1):159-168, 2000

6. Cetin F, Dincer S: The effect of intrahippocampal beta amyloid (1-42) peptide injection on oxidant and antioxidant status in rat brain. Ann N Y Acad Sci 1100: 510-517, 2007

7. Fiala $M$, Cribbs $D H$, Rosenthal M, Bernard G: Phagocytosis of amyloid-beta and inflammation: two faces of innate immunity in Alzheimer's disease. J Alzheimers Dis 11(4): 457-463, 2007

8. Halliwell B, Gutteridge JM: Free Radicals in Biology and Medicine. 3rdEdition. Oxford Science Publications, 1999

9. Keil $U$, Bonert A, Marques CA: Amyloid- $\beta$ induced changes in nitric oxide production and mitochondrial activity lead to apoptosis. J Biol Chem 279(48):50310-5020, 2004

10. Koppal T, Drake J, Yatin S, Jordan B, Varadarajan S, Bettenhausen L, Butterfield DA: Peroxynitrite-induced alterations in synaptosomal membrane proteins: Insight into oxidative stress in Alzheimer's Disease. J Neurochem 72: 310-317, 1999

11. Law A, Gauthier S, Quiron R: Say NO to Alzheimer's disease: Putative links between nitric oxide and dementia of the Alzheimer's type. Brain Res Rev 35:73-96, 2001

12. Lovell MA, Ehmann WD, Butler SM, Markesberry WR: Elevated thiobarbituric acid-reactive substances and antioxidant enzyme activity in the brain in Alzheimer's disease. Neurology 45:1594-1601, 1995

13. Machiavelli LI, Poliandri AH, Quinteros FA, Cabilla JP, Duvilanski BH: Reactive oxygen species are key mediators of the nitric oxide apoptotic pathway in anterior pituitary cells. Nitric Oxide 16(2:237-246, 2007

14. Malinski T: Nitric oxide and nitro-oxidative stress in Alzheimer's Disease. J Alz Disease 11(2):207-218, 2007 
15. Necchi D, Virgili M, Monti B, Contestabile A, Scherini E: Regional alterations of the NO/NOS system in the aging brain: A biochemical, histochemical and immunochemical study in the rat. Brain Res 933: 31-41, 2002

16. Paxinos G, Watson C: The Rat Brain: In Stereotaxic Coordinates, 4th ed. San Diego, CA: Academic Press, 1998

17. Pollack $M$, Leeuwenburgh C: Apoptosis and aging: Role of the mitochondria. J Gerontol A Biol Sci Med Sci 56(11):B475482, 2001

18. Sastre J, Pallardo FV: Mitochondrial oxidative stress plays a key role in aging and apoptosis. IUBMB Life 49:427-435, 2000

19. Siles $E$, Martinez-Lara E, Canuelo A, Sánchez M, Hernández R, López-Ramos JC: Age related changes of the nitric oxide system in the brain. Brain Res 956 (2:385-392, 2002

20. Stepanichev MY, Onufriev MV, Yakovlev AA, Khrenov Al, Peregud DI, Vorontsova ON, Lazareva NA, Gulyaeva NV: Amyloid-b (25-35) increases activity of neuronal NO-synthase in rat brain. Neurochemistry International 52: 1114-1124, 2008
21. Taskiran D, Kutay FZ, Sozmen E, Pogun S: Sex differences in nitrite/nitrate levels and antioxidant defense in rat brain. Neuroreport 8: 881-884, 1997

22. Thorns V, Lawrence HL, Masliah E: nNOS Expressing neurons in the entorhinal cortex and hippocampus are affected in patients with Alzheimer's Disease. Exper Neurol 150: 14-20, 1998

23. Vina J, Lloret A, Vallés $S L$, Borrás $C$, Badía MC, Pallardó FV, Sastre J, Alonso MD: Mitochondrial oxidant signalling in Alzheimer's disease. J Alzheimers Dis 11(2):175-181, 2007

24. Yamada K, Nabeshima T: Animal models of Alzheimer's disease and evaluation of anti-dementia drugs. Pharmacol Therap 88: 93-113, 2000

25. Zhang $Y$, Chong E, Herman B: Age-associated increase in the activity of multiple caspases in Fisher 344 rat organs. Exp Geront 37(6): 777-789, 2002

26. Zhong S, Ge Q, Qiao L, Rong Q, Ma S: Peoniflorin attenuates $A \beta(1-42)$-mediated neurotoxicity by regulating calcium homeostasis and ameliorating oxidative stress in hippocampus of rats. J Neurol Sci 280: 71-78, 2009 